
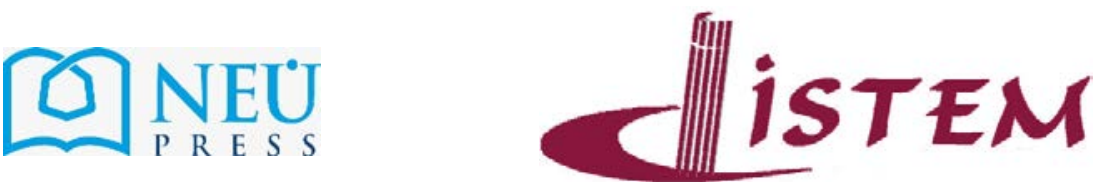

yıl / year: 18 • sayı / issue: 36 • kış / winter 2020 •s./p. 305 - 323 e-ISSN: 2602-408X

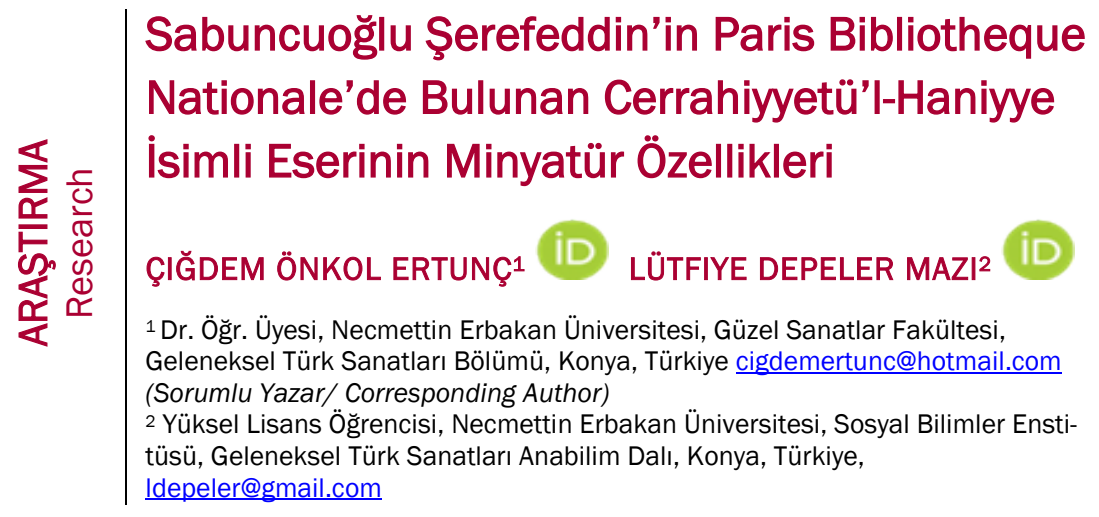

Geliş Tarihi / Received Date : 04.08.2020

Kabul Tarihi / Accepted Date : 18.10.2020

Yayın Tarihi / Published Date : 31.12 .2020

\title{
Atif/ Cite as
}

Ertunç, Çiğdem Önkol - Mazı, Lütfiye Depeler. “Sabuncuoğlu Şerefeddin'in Paris Bibliotheque Nationale'de Bulunan Cerrahiyyetü'l-Haniyye İsimli Eserinin Minyatür Özellikleri”. İstem, 18/36 (2020): 305-323. https://doi.org/10.31591/istem.815866

Öz

15. yüzyılda Amasya'da doğan Sabuncuoğlu Şerefeddin; tabâbet ilmini Burhaneddin enNahçivâni'den almıştır. Yazdığı tüm eserler tıp ve ilaç terkipleri ile alakalıdır. İımi merakı ağır basan ve oldukça ilginç bir karaktere sahip olan Sabuncuoğlu 1468'den sonra vefat etmiştir. İımi kişiliğinin yanı sıra kitaplarının hat yazılarını yazması ve minyatürlerini yapması bakımından sanatsal bir kimliğinin olduğu da bilinen Sabuncuoğlu'nun dünya tıp literatürüne kazandırdığı Cerrahiyyet'ül Haniyye kitabı, Onun tüm bu ilmi ve sanatsal kimliğini harmanlayarak ortaya koyduğu önemli bir eseridir. Cerrahiyyet'ül- Haniyye kitabı tedavi usüllerini anlatan minyatürler içermektedir. Kitap günümüze kadar genel olarak tıp bilim dalı çalışmaları açısından değerlendirilmiş ancak içerdiği Sabuncuoğlu'na ait olan minyatürler hakkında kısıtlı sayıda çalışma yapılmıştır. Bu nedenle, çalışmamızın amacı Cerrahiyyetü'ı Haniyye minyatürlerinin sanatsal açıdan değerlendirmelerini yapmaktır. Eserin birinci bâbını oluşturan dağlama tekniklerini konu alan çalışmamızda genel olarak metin minyatür ilişkisi ve minyatürlerin tasarım özellikleri tespit edilmiştir. Birinci bölümde Sabuncuoğlu Şerefeddin'in hayatı ve çalışmaları anlatılmıştır. Ikinci bölümde ise Cerrahiyyetül Haniyye'nin genel ve fiziki özellikleri hakkında bilgi verilmiş, son bölümde minyatürler hakkında genel bir değerlendirme yapılmıștır.

Anahtar Kelimeler: Sabuncuoğlu Şerefeddin, Cerrahiyyet'ül-Haniyye, Tedavi Minyatürleri, Tasvir, Dağlama.

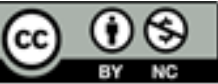




\section{Abstract \\ Miniature Characteristics of Sabuncuoğlu Şerefeddin's Cerrahiyyetül-Haniyye Work Located in Paris Bibliotheque Nationale}

Sabuncuoglu Serefeddin who was born in Amasya in 15th century received his education of medicine from Burhaneddin en-Nahcivani. All the books were written by him is about medicine and drug compounding. He who had a very curious and rather interesting character passed away in Amasya probâbly after 1468. Intellectual personality, as well as books and miniatures in the line of writing posts in terms of an artistic identity known as Al book world cerrahiyyet haniyye sabuncuoglu imparted to the medical literature, this is an important work of intellectual and artistic identity all her riffed. The book Cerrahiyyet'ül- Haniyye contains treatment procedures describing miniature. The book has been evaluated in terms of medical science studies in general and a limited number of studies have been done about the miniatures of Sabuncuoğlu. The study which includes and introduction, three main chapters and conclusion. The study aims to make artistic evaluations of Cerrahiyetül illhaniye miniatures. In our study on etching techniques that constitute the first part of the work, the relationship between text and miniature and the design characteristics of miniatures were determined. The life of Sabuncuoglu Serefeddin and his works were explained in the first chapter. The general and physical features of Cerrahiyyet'ul-Haniyye were explained in the second chapter, in the final section, a general evaluation of the miniatures was made.

Keywords: Sabuncuoglu Serefeddin, Cerrahiyyet'ul-Haniyye, Medical Illustrations, Description, Cauterization.

\section{Giriş}

Sabuncuoğlu Şerefeddin (1386/1468) tarafından 15. yüzyılda yazıımış olan Cerrahiyyetü'। Haniyye isimli eser, tıp literatüründe önemini hiçbir zaman kaybetmemiştir. Özellikle bu alanda yapılmış olan tedavi yöntemlerinin uygulanma şekillerini yazarın sanatsal kişiliği ile birleştirerek minyatürlü bir eserle ortaya koyması bakımından önemlidir. Yüzyıllar boyu farklı kültürler tarafından barındırdığı tedavi yöntemleriyle bir başvuru kaynağı özelliği taşıyan bu esere ilgi artmış, tercüme edilerek yaygınlaşması sağlanmıştır. Eser yazıldığı dönemin tıbbi bilgisini aktarmakla kalmaz aynı zamanda günümüze kadar ulaşan anlatılan ilginç tedavi yöntemleri ile alternatif tıp bilimi üzerine de ışık tutmaktadır.

Eserin bilinen üç nüshası bulunmakta ve bu nüshalar farklı kütüphanelerin koleksiyonlarında yer almaktadır. 15. yüzyılda tamamlanan eserde pek çok tedavinin farklı yöntemlerle uygulamaları ve cerrahi alet tasvirleri bulunmaktadır. Kitabın 57 fasıldan müteşekkil ilk babında dağlama yöntemleri, ikinci babında ise 98 fasıl olarak cerrahi aletler anlatılırken, 36 fasıldan oluşan son babında kırık ve çıkıklarla ilgili müdahalelere yer verilmiştir. Paris Bibliothéque Nationale, Fatih Millet Kütüphanesi nüshası ve i.Ü. Tıp Fakültesi Tıp Tarihi'nde nüshaları bulunmakta olup her bir nüshada farklı sayıda minyatür bulunmaktadır.

Çalışmamıza Sabuncuoğlu'nun Paris Bibliothéque Nationale'de Bulunan Cerrahiyyetü'l Haniyye isimli eserinin birinci bâbında bulunan dağlama metodları konu olmuştur. Genel olarak içeriğinde bulunan bâblarda detaylı olarak birçok hastalığın tedavi yöntemlerinden bahsedilen eserde dağlama yöntemlerine ayrı bir ilgi gösterilmiş ve bu yöntemler ayrıntılı bir şekilde anlatılmıştır. Eski usullerde uygulanan bu tedavi yönteminin göz, diş, karaciğer, akciğer hastalıkları tedavisinde kullanılmış olması ve bu kullanım şekillerinin tasvirlerle kuvvetlendirilmesi eserin dikkat çekici bir özelliğidir. 


\section{Sabuncuoğlu Şerefeddin Hayatı, İlmi ve Sanatsal Kişiliği}

15. yüzyıl Osmanlı devrinin önemli bir hekimi ve cerrahı olan Sabuncuoğlu Şerefeddin'in tam adı; Şerefeddin bin Ali bin el-Hac ilyas Sabuncuoğlu'dur ve şehzadeler kenti Amasya'da doğmuştur. ${ }^{1}$ Doğum tarihine dair kaynaklarda farklı rivayetler mevcut olup, 788/1386 yılında doğduğu görüşü daha fazla kabul görmüş bir malumat olarak karşımıza çıkmaktadır. ${ }^{2}$

Sabuncuoğlu Şerefeddin'in mensup olduğu aile; ilmi, mimari ve kültürel açıdan gelişmiş bir şehir olan Amasya'da tanınmış bir ulema ailesidir. ${ }^{3}$ Nitekim dedesi Hacı Illyas Bey, Çelebi Mehmet'in Amasya valiliği esnasındaki hususi hekimlerindendir. ${ }^{4}$ Ailede Sabuncuoğlu Şerefeddin'den önce meşhur hekimler yer aldığı gibi kendisinden sonra da bilinen hekimler mevcuttur. Örneğin Yavuz Sultan Selim'in İran'a kaçan oğlu şehzade Murad'ı Şerefeddin'in oğlu 5 Sabuncuoğlu İbrahim tedavi etmiştir. ${ }^{6}$ Ayrıca Hekim İsa olarak bilinen Hekim Lütfullah da Sabuncuoğlu ailesine mensup bir hekimdir.

Sabuncuoğlu Şerefeddin'in tahsil hayatına bakıldığında, onun mektep ve medrese eğitimi alıp almadığına dair kaynaklarda kesin bir bilgi bulunmamakla birlikte, tabâbet ilmini Amasya Amber bin Abdullah Dârüşşifâsı hekimlerinden olan Burhaneddin Ahmet en-Nahcivânî'den usta-çırak usulü aldığı kabul edilmektedir. ${ }^{7}$ Sabuncuoğlu tabâbet ilmini klasik tıp kitaplarını okuyarak, müşahede ve tecrübe yaparak geliştirmiştir. Hacı Paşa ve Akşemseddin onun hayranlıkla takip ettiği Türk hekimlerindendir. Müslüman hekimlerin yanı sıra kadim Yunan hekimleri Hippokrates (M.Ö. 450-300) ve Galinos da onun eserlerinde hayranlıkla sözü edilen tabiplerdir. ${ }^{8}$ Sabuncuoğlu tabâbet ilimin yanı sıra dönemin diğer tabiplerinin aksine cerrahî ile de yakından ilgilenmiştir.

Hekimlik mesleğine henüz on yedi yaşında iken yine Amasya Dârüşşifâsında başlamıştır. ${ }^{9}$ Mesleğiyle beraber tercüme ve telif işleri ile de ilgilenmiştir. Söz gelimi ỉbn-i Sina, Ebu'I Kasım Zehravî, Ebu'ı İbrahim Cürcanî gibi tıp âlimlerinin eserlerini tercüme etmiştir. ${ }^{10}$ Cerrahiyyet'ül-Haniyye eserinin telifinden sonra dönemin padişahı Fatih Sultan Mehmet'e kitabını sunmak için İstanbul'a gitmiştir.

Sabuncuoğlu Şerefeddin her ne kadar döneminin başarılı bir hekimi ve cer-

\footnotetext{
1 Nuran Yıldırım, “Sabuncuoğlu Şerefeddin”, Türkiye Diyanet Vakfı İslâm Ansiklopedisi (Erişim 09 Kasım 2019).

2 Şaban Doğan, Terceme-i Akrabâdin Sabuncuoğlu Şerefeddin (Giriş-Incleme-Metinler) Birinci Cilt (Sakarya: Sakarya Üniversitesi, Sosyal Bilimler Enstitüsü, Doktora Tezi, 2009), 15.

3 Ünal Şenel, Amasya'lı Hekim Sabuncuoğlu Şerefeddin'in Eseri Mücerreb-nâme (İzmir: Ege Üniversitesi, Sağlık Bilimleri Enstitüsü, Yüksek Lisans Tezi, 1988), 3.

4 Sibel Murad, "Terceme-i Akrabâdîn'de Terkipler ve Adlandırıımaları”, Osmanlı Bilimi Araștırmaları Dergisi 12/2 (2011), 89.

5 Vecihe Kılıcoğlu, Cerrahiye-i İlhanniye (Ankara: Türk Tarih Kurumu Basımevi, 1956), 15.

6 IIIter Uzel, Cerrahiyyetü'l-Haniyye I (Ankara: Türk Tarih Kurumu Basımevi,1992),20.

7 Uzel, Cerrahiyyetü'l-Haniyye, 21; Doğan, Terceme-i Akrabâdin,16.

8 Kılıcoğlu, Cerrahiye-i İlhanniye, 17.

9 Kılıcoğlu, Cerrahiye-i IIlhanniye, 15.

10 Şenel, Amasya'lı Hekim Sabuncuoğlu, 4.
} 
rahı olsa da Osmanlı bilim dünyasında yeterince tanınıp, tetkik edilmemiştir. $\mathrm{Ni}$ tekim ismi vefatından yaklaşık yüz yirmi dört yıl sonra ilk defa cerrah ibrahim b. Abdullah'ın 911/1505 tarihli Alâim-i Cerrahîn isimli eserinde geçmektedir. Kaynaklarda yeterince tanınmamasının sebebi olarak; eserlerini dönemin ilim ve edebiyat dili olan Farsça ve Arapça yerine Türkçe yazması, bununla birlikte zamanının meşhur hekimlerinin aksine ilgisini yalnız tıbbî ilimlere hasretmiş oluşu ve Amasya'da ikamet ediyor olması gösterilmiştir. ${ }^{11}$

Sabuncuoğlu birçok öğrenci de yetiştirmiştir. Gıyâs b. Muhammed İsfehanî, Muhyiddin Mehî onun yetiştirdiği meşhur talebelerindendir. ${ }^{12}$ Tıbbî ilim tahsili, eser telifi ve talebe yetiştirme etrafında geçen sade hayatının tam olarak ne zaman sona erdiği bilinmese de son eseri Mücerreb-nâme'yi yazdıktan sonra yani $873 / 1468$ 'den sonra vefat ettiği kabul edilmektedir. Mezarının nerede yer aldığı ise bilinmemektedir. ${ }^{13}$

Hayatını okuma, araştırma gibi kültürel faaliyetlerle idame ettirmiş Sabuncuğlu Şerefeddin dönemin ilim ve edebiyat dili olan Arapça ve Farsçayı çok iyi derecede bilmektedir. Bununla birlikte Mücerreb-nâme'sinde geçen "ben bu nüshaı kitab-ı yunanî den istihrac itdüm" ibaresinden onun Yunanca da bildiği düşünülmektedir. ${ }^{14}$ Tüm bunlara rağmen eserlerini Türkçe yazması onun dikkat çeken özelliklerindendir. Cerrahiyyetü'l-Haniye'sinde dönemin Arapça ve Farsça bilmeyen hekim ve cerrahlarının istifadesi için Türkçe yazmayı tercih ettiğini bildirmektedir. ${ }^{15}$ Eserlerini sade ve anlaşılır bir dil ile yazması onun Türk dili ve Tıp tarihi açısından kıymetini daha da arttırmaktadır. ${ }^{16}$ Eserlerini, nesih hattına oldukça yakın bir karakterle ile zamanına göre başarılı bir şekilde kaleme almıştır.

Cerrahiyyetü'l-Haniyye minyatürlerini resmetmiş olması ${ }^{17}$ ile de tanınan Sabuncuoğlu'nun sanatçı bir kişiliği olduğunu söylemek mümkündür. Bir tıp hekiminin sanata ilgi duyması Türk sanatları konusunda intisas sahibi pek çok hocanın da geçmişinde tıp ilmi ile uğraşmış olması ile alakalı önemli bir benzerliktir. Bilinen tüm eserleri tıbbî ilimler ile alakalı olan Sabuncuoğlu Şerefeddin'in üç eseri ve dört otografı bulunmaktadır ${ }^{18}$. Bunlar kronolojik sıraya göre; Terceme-i Akrabâdîn, Halimî'nin manzum tıp kitabı, Cerrahiyyetü'lHaniyye, Müfid (Nazmü’t-Teshîl) ve Mücerreb-nâme'dir'19.

\footnotetext{
11 Kılıcoğlu, Cerrahiye-i IIIhanniye, 2.

12 Uzel, Cerrahiyyetü'l-Haniyye, 21.

13 Uzel, Cerrahiyyetü'l-Haniyye, 23.

14 Uzel, Cerrahiyyetü'l-Haniyye, 23.

15 Uzel, Cerrahiyyetü'l-Haniyye, 34; M. Șerafettin Canda, “Türkiye'de Nöropatoloji Gelișimi Dünden Bugüne", Türkiye Ekopatoloji Dergisi 11/3 (2005), 99.

16 Doğan, Terceme-i Akrabâdin, 16.

17 Uzel, Cerrahiyyetü'l-Haniyye, 35.

18 Uzel, Cerrahiyyetü'l-Haniyye, 24.

19 Kılıcoğlu, Cerrahiye-i ilınanniye , 20.
} 


\section{Cerrahiyyetü’I-Hâniyye}

Hicrî 870/miladi 1465 yılında yazılan Cerrahiyyetü'l-Hâniyye, Sabuncuoğlu Şerefeddin'e dünya çapındaki ününü kazandıran eserdir. ${ }^{20}$ Bu eserin en önemli hususiyeti, İslam tarihinde tasvirli minyatürler kullanılarak hazırlanmış ilk tıbbî eser olmasıdır. ${ }^{21}$ Kitapta birçok tedavi yöntemleri ve cerrahi müdahaleler resmedilerek anlatılmıştır. Bazı kaynaklarda bu kitabın orijinal bir eser olmayıp, XI. yüzyılın meşhur cerrahlarından Ebu'I-Kasım Zehravî'nin Kitâb et-Tasrif fî't-Tıbb isimli eserinin bir tercümesinden oluştuğu bilgisi mevcuttur. Ancak Cerrahiyyet'ül-Haniyye'nin tasnifi et-Tasrif'in “kitâb el-a'mâl fi'l-yed” başlıklı cerrahî bölümü/ otuzuncu bölümü ile paralellik arz etse de birebir tercümesi değildir. Sabuncuoğlu Şerefeddin'in kendi tecrübelerini de içermektedir. Söz gelimi temriye ile alakalı bölüm, uçuğun dağlanması ve akrabadîn fasılları Sabuncuoğlu'nun kaleminden çıkmıştır. Akrabadin'in kelime manası tıbbi formüller anlamına gelmektedir. ${ }^{22}$ Ayrıca et-Tasrif yalnızca tıbbî aletlerin resmini içerirken; Cerrahiyyet'ül-Hâniyye'de aletlerle birlikte bu tıbbî aletlerin nasıl kullanılacağını da gösteren minyatürler bulunmaktadır. ${ }^{23}$

Üzerinde deontolojiden Türk dil tarihine pek çok akademik araştırma yapılan bu eserin bilinen üç nüshası mevcuttur. Bunlar Fatih Sultan Mehmed'e ithaf edilen Paris Bibliothéque National nüshası, Fatih Millet Kütüphanesi nüshası ve i.ü. Tıp Fakültesi Tıp Tarihi nüshasıdır.

Yapılan literatür tetkiklerinde çalışmamızın konusunu teşkil eden Paris nüshasında bulunan minyatürlerin sanatsal açıdan pek bir değerinin bulunmadığına değinilmiş olup, İstanbul nüshasında bulunan ve teknik ve üslup özellikleri bakımından diğer iki nüshadan ayrılan nüshanın bu açıdan daha ehemmiyet içerdiğine dair görüşler bulunmaktadır. Çalışma konumuz olan Paris nüshasında bulunan yazma eserdeki minyatürlerin içerdiği figürler, nebatatlar, alet tasvirleri ve cerrahi müdehaleler minyatür sanatının ifadesel anlatım gücünden yola çıkarak, resim metin analizleri bakımından sanat değeri taşıyan önemli vesikalar olduğu kanaatindeyiz. Suut Kemal Yetkin'de İslam Minyatürünün Estetiği isimli makalesinde "Umumiyetle bir tablonun ne demek istediğini daha anlamadan renk ve çizgi âhenginin sihirli tesirinde kalırız. Zaten sanat bu sihirli âhenkten başka bir şey değil midir ${ }^{24}$ ?" ifadesiyle her bir çizginin her bir rengin veya kullanılan her bir figürün nesneye estetik bir olgu kazandırdığını destekler niteliktedir.

20 Volkan Acar, “Cerrahiyyetü’l-Haniyye Hakında Yazılan Türkçe Makaleler”, Lokman Hekim Dergisi 5/2 (2015), 37-44.

21 Gönül Güreşsever,“Kitab Al-Cerrahiyet Al-Hâniye (İstanbul Tıp Tarihi Enstitüsü Nüshası) Minyatürleri”, I. Milletlerarası Türkoloji Kongresi (15-20 Ekim 1973): Tebliğler, (İstanbul: İstanbul Üniversitesi Edebiyat Fakültesi Türkiyat Enstitüsü Yayınları, 1979), 772.

${ }^{22}$ Haldun Eroğlu, "XV. Yüzyıl Tabiblerinden Şerafettin Sabuncuoğlu ve Amasya Dârüşşifâsı”, Ankara Üniversitesi Osmanlı Tarihi Araştırma ve Uygulama Merkezi Dergisi 11 (2000), 150.

${ }^{23}$ Nuran Yıldırım, “On Beşinci Yüzyıla Ait Türkçe Cerrahnâmeler”, Lokman Hekim Journal 1/1(2011), 21; Uzel, Cerrahiyyetü'l-Haniyye, 26.

${ }^{24}$ Suut Kemal Yetkin, “İslam Minyatürünün Estetiği”, Ankara Üniversitesi Illahiyat Fakültesi Dergisi 1 (1953), 34. 


\subsection{Fatih Millet Kütüphanesi Nüshası}

Fatih Millet Kütüphanesinde Ali Emirî Kitaplığı 79 numarada kayıtlı olan Millet nüshası da Paris nüshasıyla aynı tarihte Sabuncuoğlu Şerefeddin tarafından Amasya'da hazırlanmıştır ${ }^{25} .199$ varaktan oluşan yazma, kalın abadî kâğıt üzerine yazılmıştır ve sonradan yapılmış bir bez cilt içindedir. Harekeli, okunaklı nesih ile kaleme alınmıştır. ${ }^{26}$ Sayfanın ebadı $16,4 \times 25,3 \mathrm{~cm}$.; yazıyı çerçeveleyen cetvel ise $13,1 \times 20,8 \mathrm{~cm}$ 'dir. Her sahife kırmızı/lâl mürekkep ile cetvel içine alınmıştır. Metin kısımları 17 satır olacak şekilde düzenlenmiştir. ${ }^{27}$ Bâb ve fasıl başlıklarının yanı sıra önemli addedilen bazı kısımlar da lâl mürekkep ile yazıımıştır. Sayfa düzeni, yazııış şekli bakımından Paris nüshası ile benzerlik arz etmektedir. Yine Paris nüshası ile aynı şekilde üç bâbtan oluşan Millet yazması ne yazık ki onun kadar iyi korunamamıştır. Pek çok bölümü eksiktir. Bu eksikliklerin bir kısmı acemi (minyatürlerin çalakalem çizilmeye çalışılması hususu bu fikri ortaya koymaktadır) bir şekilde tamamlanmaya çalışılsa da halen pek çok fasıl eksiktir. ${ }^{28}$

\section{2. İ.Ü. İstanbul Tıp Fakültesi Tıp Tarihi Nüshası}

İstanbul Tıp Fakültesi Tıp Tarihi Enstitüsü'ne bağlı Tıp Tarihi Müzesinde sergilenen bu nüshanın tam olarak ne zaman ve kim tarafından istinsah edildiği bilinmemektedir. Müzeye General Prof. Besim Ömer Akalın'nın hususi kütüphanesinden intikal etmiştir. ${ }^{29}$ Kitabın minyatür ve yazı kısımlarının üslup özelliklerinden yola çıkılarak kitap yaklaşık olarak 16 . veya 17 . yüzyıllara tarihlenebilir. 30

Bu nüsha her ne kadar yüksek sanatsal özellikler içermekte ise de gerektiği gibi muhafaza edilmemiştir. Tahribata uğrayan ve pek çok eksiklik içeren nüsha 188 varaktan oluşmaktadır. Deri cild içinde muhafaza edilen eserin sayfa ebadı 30x21 iken; metni sınırlayan cetvel 18,3×12'dir. ${ }^{31}$ Cetveller kırmızı/lâl mürekkep ile çekilmiş metin kısmı 15 satır şeklinde düzenlenmiştir. ${ }^{32}$ Bu nüshadaki minyatür sayısı, takdim sayfası kayıp olduğundan, tam olarak bilinememektedir. Günümüzdeki eksik nüshada ise yalnızca 32 minyatür bulunmaktadır. Minyatürlerin hemen hepsi yarım sayfa ebadındadır. Minyatürlerin diğer iki nüshadan farklı olarak daha sanatsal olmaları ve klasik minyatür üslubuna yakın bir üslup taşıması bu minyatürlerin usta bir nakkaş elinden çıkmış olduğunu düşündürmektedir (Resim 2). ${ }^{33}$

\footnotetext{
25 Kılıcoğlu, Cerrahiye-i illhanniye, 25.

26 Uzel, Cerrahiyyetü'l-Haniyye, 29.

${ }^{27}$ A.Süheyl Ünver, Cerrahiyei İlhaniye (İstanbul: Kenan Basımevi,1939),13.

28 Kılıcoğlu, Cerrahiye-i ilhanniye, 25.

29 Güreșsever,"Kitab Al-Cerrahiyet Al-Hâniye (İstanbul Tıp Tarihi Enstitüsü Nüshası) Minyatürleri",773.

30 Ünver, Cerrahiye-i IIIhaniye, 15.; Kılıcoğlu, Cerrahiye-i İlhanniye, 25.

31 Güreşsever,"Kitab Al-Cerrahiyet Al-Hâniye (İstanbul Tıp Tarihi Enstitüsü Nüshası) Minyatürleri",774.

32 Güreşsever, “Kitab Al-Cerrahiyet Al-Hâniye (İstanbul Tıp Tarihi Enstitüsü Nüshası) Minyatürleri",774.

33 Güreşsever,“Kitab Al-Cerrahiyet Al-Hâniye (İstanbul Tıp Tarihi Enstitüsü Nüshası)
} 


\subsection{Paris Bibliothéque Nationale'de Bulunan Cerrahiyyetü’l Haniyye Nüs- hasının Minyatür Özellikleri}

Fatih Sultan Mehmet'e arz edilmek ve O'nun merhametini elde etmek üzere Sabuncuoğlu Şerefeddin tarafından 870/1465'de Amasya'da hazırlanan bu nüsha, Paris Bibliothéque Nationale (Suppl., Turcs, nr. 693)'de yer almaktadır. ${ }^{34}$ Saray kütüphanesinden ne zaman çıkartıldığı bilinmeyen bu kıymetli nüsha; 1860 yılında Yâsincizâde Mehmet İlmî Efendi tarafından Fransız bir hekime hediye edilmiştir. Yazmanın Paris Bibliothéque Nationale'e intikali 1871 senesinde olmuştur. ${ }^{35}$ Çalışmamıza konu olan bu nüshanın kahverengi meşin bir cilt içinde bulunan eserin ebadı 18×26,5 cm'dir${ }^{36}($ Resim 3). Mıklebi olan cilt son derece sadedir. Ön ve arka kapağının yüzeyinde ufak tefek tahribat görülen cildin ön ve arka kapaklarının ortasında eşkenar dörtgen formunda oldukça küçük bir tezyini unsur bulunmaktadır. Cildin iç kısmı ve ondan sonra gelen ilk sayfalar kalın abadî kâğıttandır ${ }^{37}$, aharıdır ve tezyin edilmemiştir. Yazmanın ilk ve son sayfasında II. Bâyezid'in tuğrası bulunmaktadır. ${ }^{38}$ Bununla beraber yazmanın ilk sayfasında Paris Bibliotheque Nationale mührü de yer almaktadır.
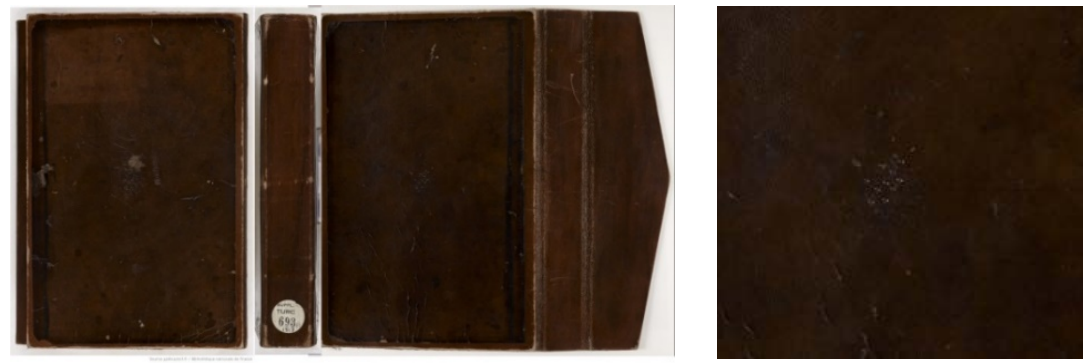

Resim 1 Cildin genel ve detay görünümü

Kitapta sayfa düzeni 17 satır şeklinde ayarlanmış ve sayfa lâl mürekkep ile çift cetvel içine alınmıştır (Resim 4). Zamanına göre başarılı nesih hattını andıran bir yazı ile Osmanlıca kaleme alınan eserin tamamı harekelidir. Siyah mürekkep ile yazılan hattın harekeleri de siyahla çekilirken; başlıklar ve dikkat çekilmek istenen noktalar lâl mürekkep ile yazılmıştır. Genellikle aynı ölçülerde yazılmış kelimeler, 17 satırlık ölçüyü bozmamak adına, zaman zaman daha küçük yahut cetvel sınırını biraz aşacak şekilde yazılmıştır.

$$
\rightarrow \rightarrow
$$

Minyatürleri”,774.; Ünver, Cerrahiye-i IIIhaniye, 25.; Kılıcoğlu, Cerrahiye-i İlhanniye, 25.

${ }^{34}$ Ali Haydar Bayat, "Cerrâhiyye-i İlhâniyye”, Türkiye Diyanet Vakfı İslâm Ansiklopedisi (Ankara: TDV

Yayınları, 1993), 7/420.

35 Kılıcoğlu, Cerrahiye-i illhanniye, 23.

36 Ünver, Cerrahiye-i İIhaniye,.15; Uzel, Cerrahiyyetü'l-Haniyye, 28.

37 Uzel, Cerrahiyyetü'l-Haniyye, 28.

38 Kılıcoğlu, Cerrahiye-i illhanniye, 23. 


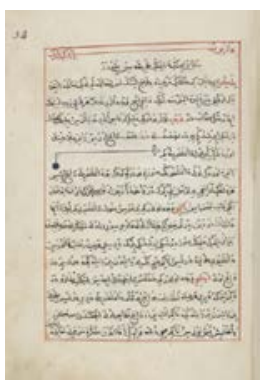

Resim 2 34a numaralı varak genel görünüm

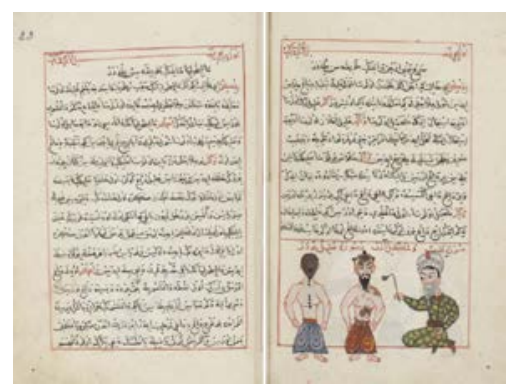

Resim $322 b$ ve 23a numaralı varak genel görünüm

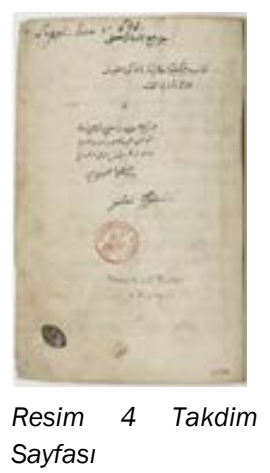

Sayfası

Tedavi yöntemlerini açıklayan fasılların birçoğunun sonunda minyatür bulunmaktadır. ${ }^{39}$ Minyatürler de lâl mürekkep ile çift cetvel içine alınmıştır. Lâl mürekkep ile yazılan, siyah mürekkep ile harekelendirilen minyatürlerin açıklayıcı notları çoğunlukla resmin cetvelinin içinde yer almaktadır. Ayrıca tedavi için kullanılan bazı aletlerin ve yapılan müdahalelerin resmi de metin içinde gösterilmektedir. ${ }^{40}$ Tedavi sahneleri kadar çok sayıda olmayan bu alet çizimleri çoğunlukla metin içinde cetvelsiz şekilde iken; bazen de cetvelli olarak resmedilmiştir.

Kitap üç bâbdan oluşmuştur. Eserin birinci bâbında 57, ikinci bâbında 98, üçüncü bâbında ise 36 fasıl bulunmaktadır. Sabuncuoğlu eserini resimlerken birinci bâbda 54 tedavi, 7 alet ve 4 inzisyon, ikinci bâbda 58 tedavi, 131 alet ve 10 inzisyon ve üçüncü bâbda 24 tedavi ve 11 alet olmak üzere 136 tedavi gösterir resim ile oluşturmuştur. ${ }^{41}$

Eserin ilk sayfasında yani 1a numaralı varakta eserin ne kitabı olduğu, kime hibe edildiği, hangi kitaplıkta ve hangi numarada kayıtlı olduğu gibi bilgiler Arapça, Osmanlıca ve Fransızca olarak verilmiştir. Bundan sonra 3 sayfa takdim sayfası bulunmaktadır. Takdim bölümünün yaklaşık 2,5 sayfa mensur, yarım sayfasına yakın beş satırlık kısmı da manzum şekilde yazıımıştır. Takdimin hemen akabinde 23 sayfalık fihrist bölümü bulunmaktadır. Fihristte bâb ve fasıl başlıkları lâl mürekkep ile yazılırken; içerik kısımları siyahla yazılmıştır. Üç bölümden oluşan eserin ketebe kısmı da bulunmaktadır. Bu şekliyle toplamda 205 varaktan oluşmaktadır. ${ }^{42}$

\footnotetext{
39 Uzel, Cerrahiyyetü'l-Haniyye, 28.

40 Bayat, ' Cerrâhiye-i İlhâniyye', 7/420.; Uzel, Cerrahiyyetü'l-Haniyye, 28.

${ }^{41}$ Eroğlu, 'Şerafeddin Sabuncuoğlu', 154.

42 Uzel, Cerrahiyyetü'l-Haniyye, 28.
} 


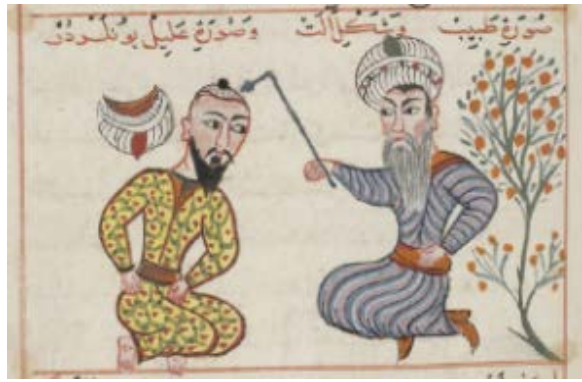

Resim 5 17a'da bulunan minyatürün genel ve detay görünümü. Başta rutubet üstünlüğünden dolayı oluşan baş ağrılarının tedavisi için dağlama tekniğinin kullanımı.

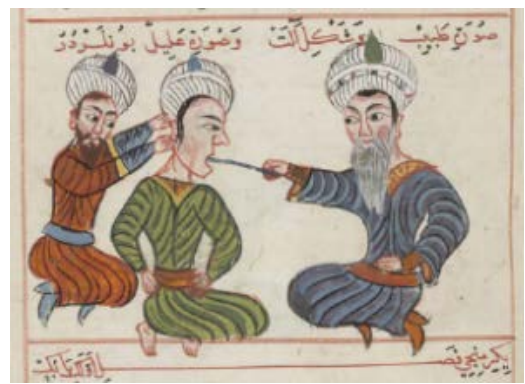

Resim 7 28a'da bulunan minyatürün genel ve detay görünümü. Ağız içinde çıkan nasırların dağlama tekniği ile tedavisi.

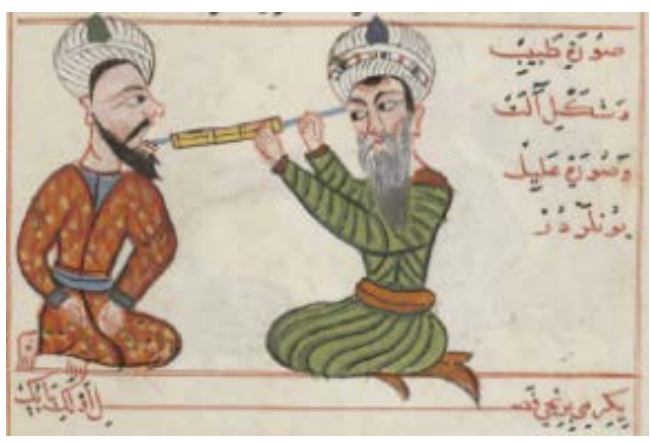

Resim 9 28b'de bulunan minyatürün genel ve detay görünümü. Diş ağrısı tedavisinin dağlama yöntemiyle yapılışı.

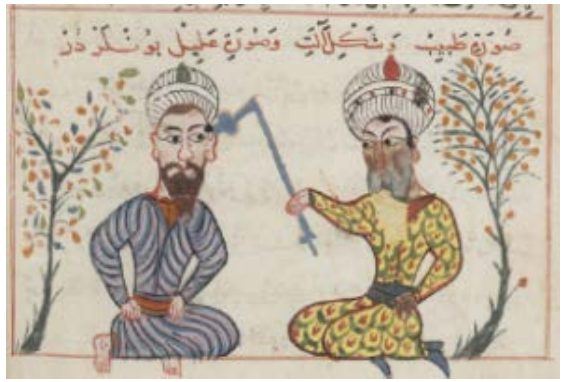

Resim 6 18b'de bulunan minyatürün genel ve detay görünümü. Yeni oluşmuş baş ağrısının tedavisi için dağlama yönteminin kullanılması

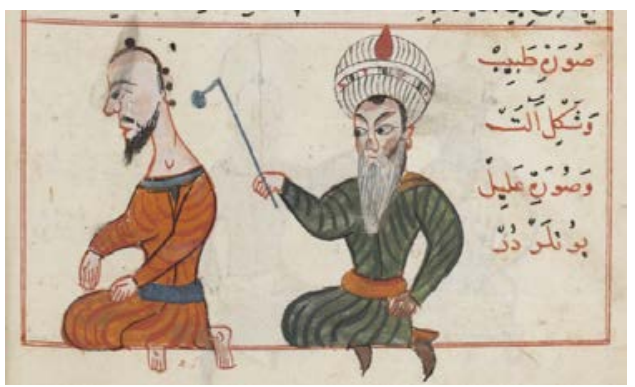

Resim 8 21b'de bulunan minyatürün genel ve detay görünüm. Balgamdan kaynaklanan unutkanıı̆ın dağlama yöntemiyle tedavisi.

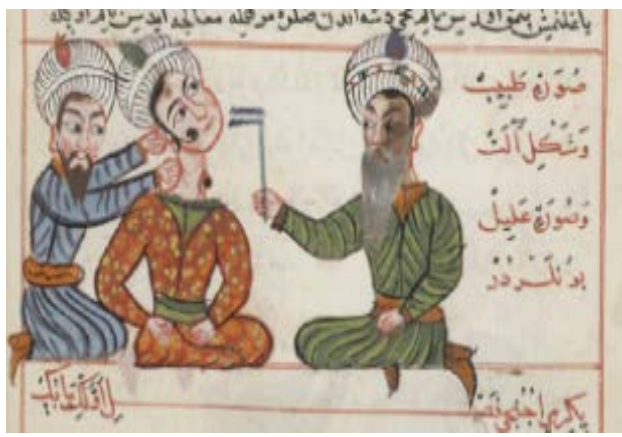

Resim 10 29b'de bulunan minyatürün genel ve detay görünümü. Domuz başı hastalığının tedavisinde dağlama tedavisi uygulanması. 


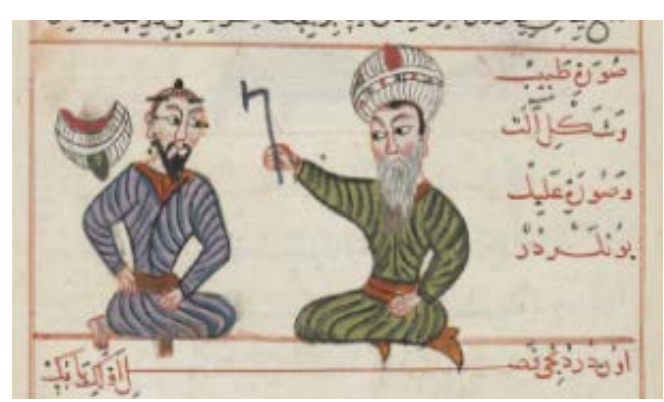

Resim 11 24a'da bulunan minyatürün genel ve detay görünümü. Durmadan akan göz yaşının tedavisi için kullanılan dağlama tedavisi.

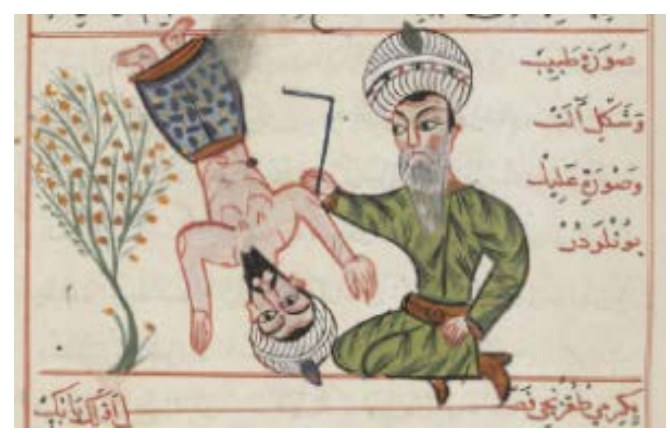

Resim 13 33a'da bulunan minyatürün genel ve detay görünümü. Karaciğer tümörünün dağlama yöntemiyle tedavisi.

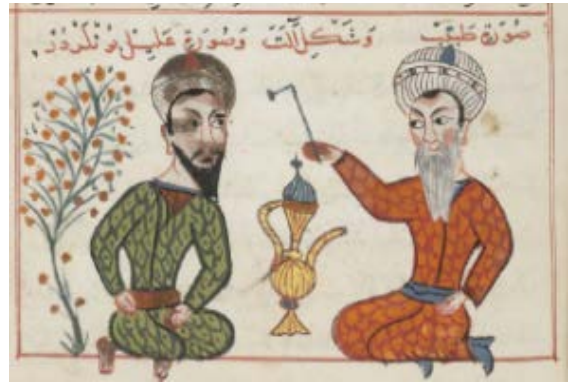

Resim 12 26a'da bulunan minyatürün genel ve detay görünümü. Kirpiklerin eğilmesi için tedavi amaç/ı dağlama yöntemi.

$\underset{36 / 2020}{\mathbf{i}}$

$\mathbf{S}$ $\mathbf{T}$ E $36 / 2020$

Birinci bâbda kara sevda, karaciğer tümörü, göz hastalıkları ve diş hastalıkları gibi çeşitli hastalıklar ve dağlama ile tedavisini, ikinci bâb cerrahiyye konusunu, üçüncü bâb ise kırık çıkıkların tedavi yöntemlerini işlemektedir. Çalışmamıza konu olan birinci bâbda uygulanacak tedavilerin minyatürleri bizzat hekimin elinden çıkmıştır.

Tedavi sahnelerinden ve tedavi yöntemlerinin yazıldığı birinci bâbda ortalama her sayfada minyatür bulunmaktadır (Resim 5-13). Her biri ilgili faslın metin kısmının sonuna yerleştirilmiştir. Bu minyatürler tedavi edilmek istenilen hastalıkların görsel olarak ifade edilmiş şeklidir. Bir nakkaş değil de hekimin elinden çıktığı için devrinin minyatür anlayışından daha uzak ve iptidai resimlerdir. İnsan figürleri anatomik olarak orantısız resmedilmiştir. Söz gelimi hekimin yahut hasta figürlerinin üst bedenleri, alt bedenlerine göre daha büyük; el ve ayakları oldukça ise oldukça küçük çizilmiştir. Bazı resimlerde parmak sayıları dört iken bazılarında altıdır. Bunun yanı sıra minyatürlerde iç veya dış mekân olgusu bulunmamaktadır. Resimde kullanılan elamanlar şematik olarak 
ifade edilmiştir. ${ }^{43}$ Resimlerde hasta, hekim, yardımcı hekim ve kenarlara serpiştirilen bitkilerin dışında başka öğe kullanılmamıştır. Sadece bir tasvirde dekoratif unsur olarak ibrik bulunmaktadır.

Tüm fasıllarda figürlerin ten ve göz renkleri ile bedenlerinin konturu için kullanılan renk aynıdır. Figürlerin yüzlerine canlıık katmak için uygulanan kırmızı ile pembe arası renk de bedenlerin konturunda kullanılan renkle aynıdır. Kıyafetlerde kullanılan renk ve desenler de benzerlik arz etmektedir. Çoğu kıyafet aynı şekliyle ve rengiyle birçok fasılda tekrar tekrar resmedilmiştir. Hekim figürleri tüm fasıllarda oturur pozisyonda, pabuçlu ve benzer surette tasvir edilmiştir. Hasta veya yardımcı hekim diyebileceğimiz üçüncü figürler kimi zaman sakallı, kimi zaman çocuk suretli çizilmişlerdir. Ama birinci ve otuzuncu fasıllar arasındaki hasta ve yardımcı figürlerin hepsi de genç ve erkek olarak tasvir edilmiştir.

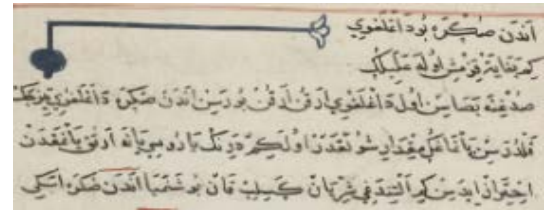

Resim 14 Üçüncü fasıl 18b’de bulunan Suret-i Alet.

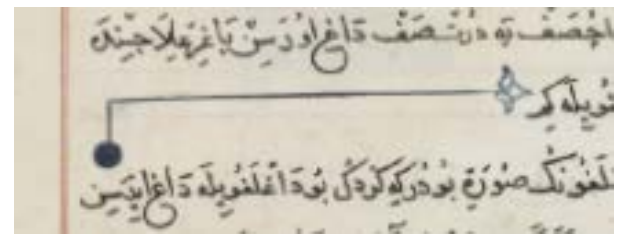

Resim 16 Otuzuncu fasıl 34a'da bulunan Suret-i Alet

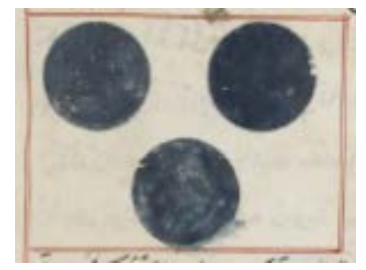

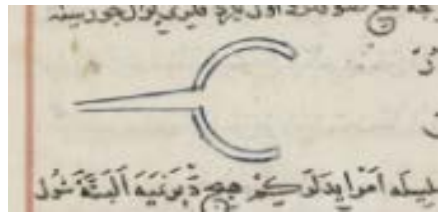

Resim 15 Onyedinci fasıl 27a'da buIunan Suret-i Alet

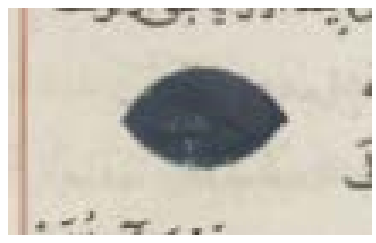

Resim 17 On altıncı fasıl 25b numarada bulunan insizyon tasviri.

\section{i}

Resim 18 Yirmi altıncı fasıl 31b de bulunan inzisyon tasviri.

Dağlama metotlarının çeşitli hastalıklarda verdiği neticelerin ve sağladığı şifanın anlatılı̆̆ı birinci bâbda metin kısmı içinde ayrıca resmedilen suret-i alet

\footnotetext{
43 Güreşsever, “Kitab Al-Cerrahiyet Al-Hâniye (İstanbul Tıp Tarihi Enstitüsü Nüshası) Minyatürleri”, 776.
} 
tasvirleri bulunmaktadır. Bunlar üçüncü, on yedinci ve otuzuncu fasılların metin kısmı içinde ve ayrıca cetvel içine alınmamış şekildedir. Üç resim de aynı ton koyu gri/ kurşunî ile çizilmiştir (Resim 14-18). Dağlama yöntemlerinin anlatıldığı birinci bâbda, dağlamanın tekniği ve aletler tasvir edilirken bu aletlerin vücud üzerinde bırakacağı izleri anlatmak için de ayrıca tasvirler bulunmaktadır. Inzisyon olarak adlandırılan bu izleri metin içerisinde minyatürlere nazaran daha küçük ve koyu mürekkep kullanılarak resmedilmiştir.

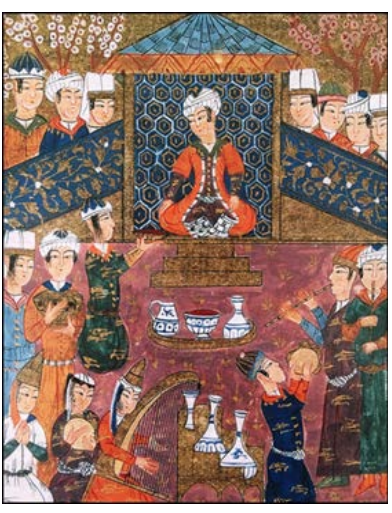

Resim 19 Külliyat Kâtibi (And, 2002)

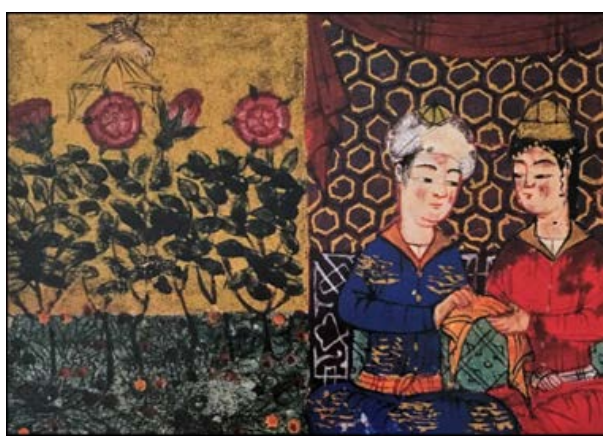

Resim 20 Dilsuzname (Bağcı vd., 2006)

Sanata ve sanatçıya verdiği önem ile Türk kitapçılık tarihinde tamamıyla kendine özgü ürünler çıkaran 15. yüzyıl saray nakkaşhanesinde üretilen tezhip ve minyatürlü yazmalarda üslup birliği bulunmaktadır ${ }^{44}$. Cerrahiyyet'ül Haniyye'nin 15. yüzyıla ait olması bu dönemde sanatın önemli merkezlerinden biri olan Edirne Nakkaşhanesinde yapılmış olması olasılığını ortaya çıkarsa da, eser hem üslup hemde estetik yönden nakkaşhanede üretilen diğer az sayıda eserle benzerlik taşımamaktadır. $\mathrm{Bu}$ nedenle eserin tamamen Sabuncuoğlu'nun kendi fırçasından çıktığı anlaşılmaktadır. 15. yüzyılda yapılmış 1460-80 tarihli Ahmedî İskendernâme'sinin özellikle Venedik Marciana Kitaplığında bulunan nüshasının, 1455-56 tarihli Dilsuzname'nin, aynı yıllara tarihlenen Külliyat-ı Kâtibî’nin minyatürlerinin tipik Edirne Nakkaşhanesi üslup özelliklerini taşımaktadır. Anlatılmak istenen konunun alanın merkezine yerleştirilmesi, Türkmen ve Timurlu minyatürlerinden görülen sahne anlayışılla benzerlik taşır(Resim 19-20). Doğa tasvirlerinin bolca kullanıldığı minyatürlerde derinlik hissinin hakimiyeti hissedilir. Figür duruşlarının genel olarak üst üste yerleştirildiği kompozisyonlarda genel olarak kırmızı, turuncu, mavi, lacivert, sarı, eflatun ve yeşil gibi renklerin kullanımıyla sahnelerde canlı bir görünüm vurgulanır. Her iki eserde de minyatürler çift sayfa ve dış mekanda resmedilmiş, kalan boşluklarda ağaç ve doğa tasvirlerin resmedilmiştir. Paris nüshası minyatürleri şematik bir şekilde olup, mekan fikri olmayan, çizgisel ifadelerin yoğunlukla kullanıldığı bir üslup göstermektedir. Çalışma konumuzu teşkil eden Paris Nüs-

${ }^{44}$ Ali Fuat Baysal, "Mushaf Tezyinatının Tarih İçindeki Gelişimi”, Marife Dini Araştırmalar Dergisi 10/3 (2010), 370. 
hasının var olan minyatür geleneğinden farklı bir üslupta olması bu eserin Amasya'da yetişmiş sanatçının fırçasından çıktığını da ortaya çıkarır ${ }^{45}$.

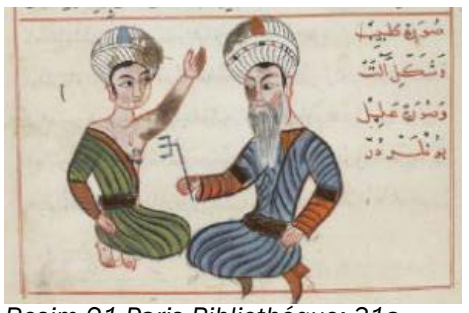

Resim 21 Paris Bibliothéque: 31a

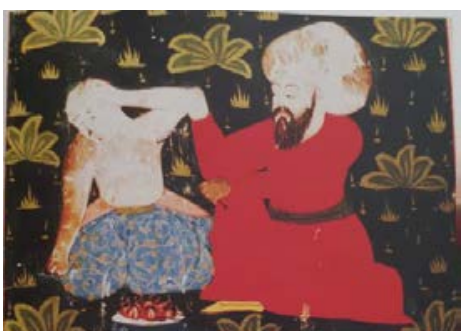

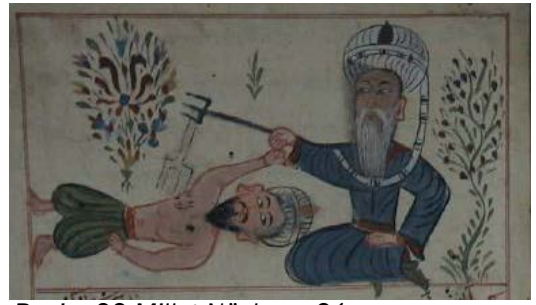

Resim 22 Millet Nüshası: 31a

Resim 23. Tıp Tarihi Müzesi Nüshası: 2b

(Uzel, 1992)

Rutubet üstünlüğünden oluşan omuz çıkığında dağlama metoduna ait üç nüshada bulunan minyatürler

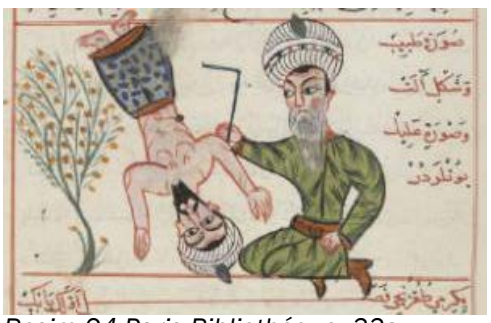

Resim 24 Paris Bibliothéque: 33a

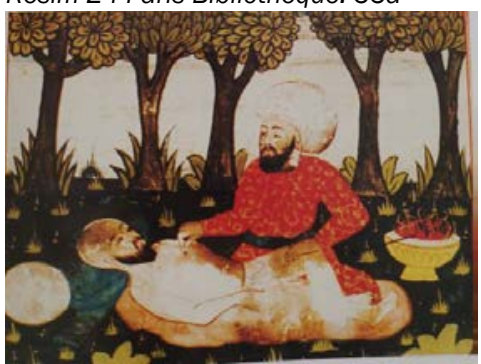

Resim 26 Tıp Tarihi Müzesi Nüshası: 6a (Uzel, 1992)

Karaciğer tümörünün dağlama metoduna ait üç nüshada bulunan minyatürler

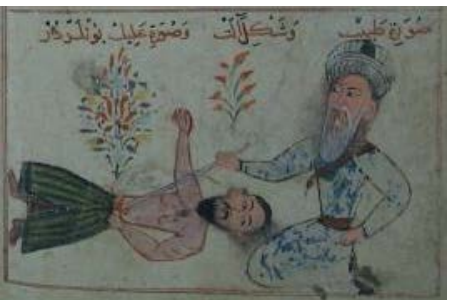

Resim 25 Millet Nüshası: 32b i

\footnotetext{
45 Oktay Aslanapa, “Osmanlı Minyatür Sanatı”, Yeni Türkiye Dergisi 34/6 (2000), 654.
} 


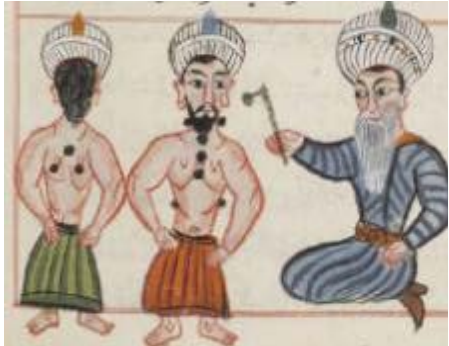

Resim 27 Paris Bibliothéque: 33b

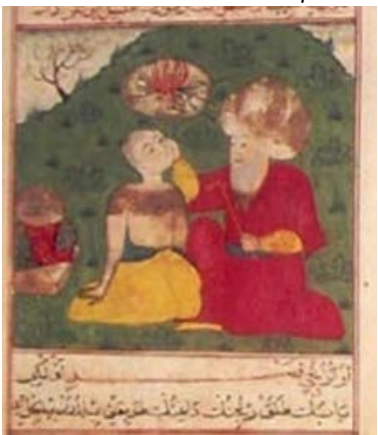

Resim 29 Tip Tarihi Müzesi Nüshası: $7 a$ (Uzel, 1992)

Plörezinin (akciğer zarında sıvı birikmesi) dağlanma metoduna ait üç nüshada bulunan minyatürler

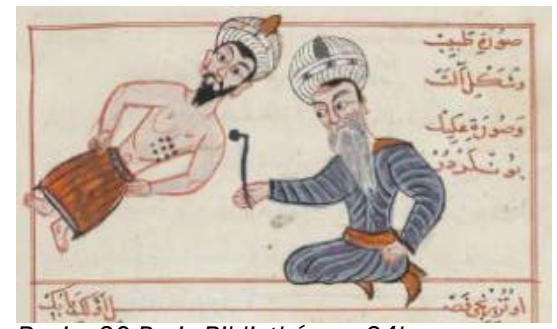

Resim 30 Paris Bibliothéque: 34b

$M$ $36 / 2020$

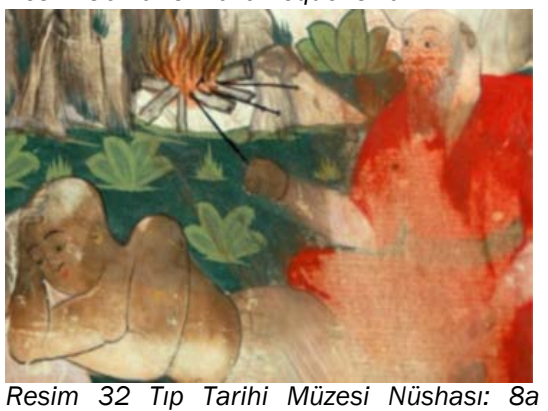

(Uzel, 1992)

Dalak hastalıklarının dağlanma metoduna ait üç nüshada bulunan minyatürler

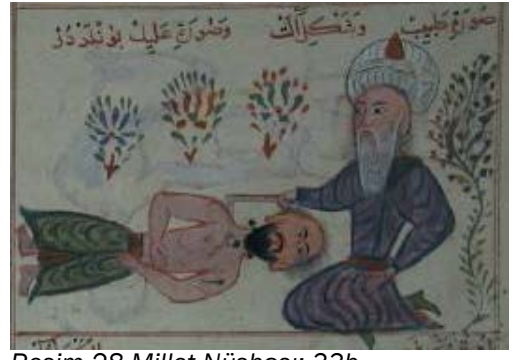

Resim 28 Millet Nüshası: 33b

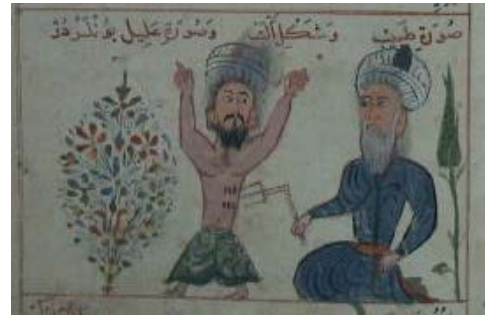

Resim 31 . Millet Nüshası: 34a 


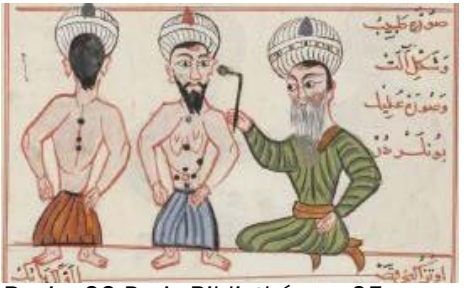

Resim 33 Paris Bibliothéque: 35a

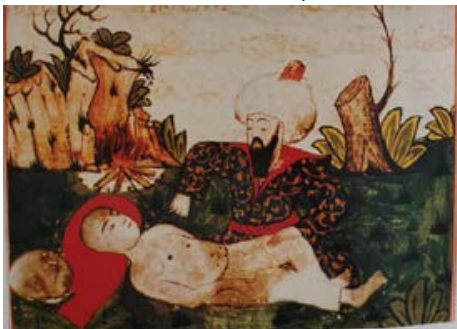

Resim 35 Tıр Tarihi Müzesi Nüshası: 9a (Uzel, 1992)

Sirozun (İstinkanın) dağlanma metoduna ait üç nüshada bulunan minyatürler

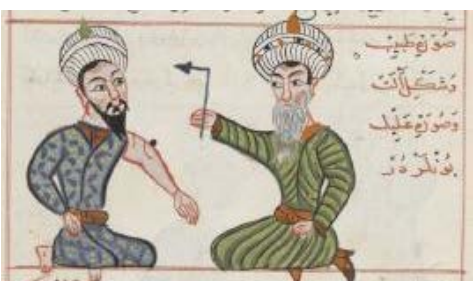

Resim 36 Paris Bibliothéque: $45 b$ Mafsal yırtığının dağlama metodunun iki nüshada bulunan

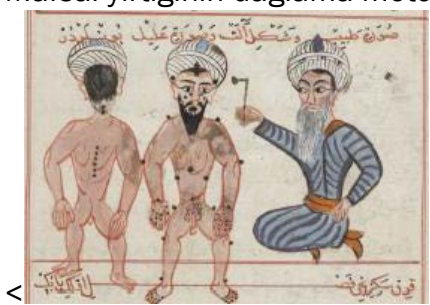

Resim 38 Paris Bibliothéque: $46 b$

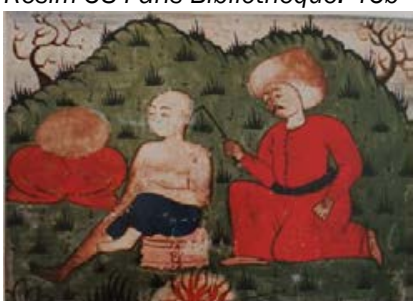

Resim 40 Tıp Tarihi Müzesi Nüshası: 23b

(Uzel, 1992)

Cüzzamın dağlanma metoduna ait üç nüshada bulunan minyatürler

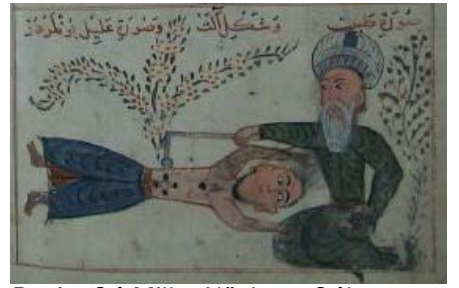

Resim 34 Millet Nüshası: 34b

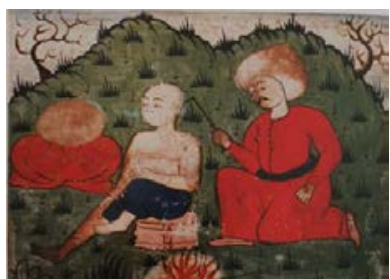

Resim 1 Tıp Tarihi Müzesi Nüshası: 23b

hada bulunan minyatür

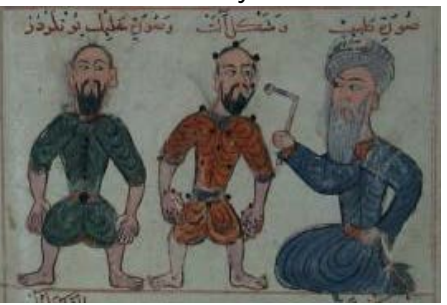

Resim 39 Millet Nüshası: 40b 
Çalışmamıza konu olan Paris nüshası dağlama metotlarında bulunan minyatürlerin her üç nüshada da bulunan tasvirlerinin bulunduğu metodlarda üç nüshanın arasındaki farklılıkların tespiti açısından değerlendirmeye alınmıştır. Fatih Millet Kütüphanesi nüshası minyatür özellikleri bakımından diğer iki nüshadan daha iptidai özellikler gösterir. Bu nüshayı Sabuncuoğlu'nun kendisine saklamak için kaleme aldığı tahmin edilmektedir. ${ }^{46}$ İstanbul Tıp Tarihi Nüshası yapılış zamanı ve üslup özellikleri dolayısıyla minyatürleri diğer iki nüshadan farklıdır. Minyatürlerin hemen hepsinde üslup birliği bulunup irili ufaklı nebati tasvirlerle hareketlendirilmiş, tabiat tasvirlerindeki ayrıntıcı bezeme özellikleri ile dikkati çeker. Figürlerin oldukça büyük tasvir edilmesi, Anadolu Türk tipinde olmaları ve bazen hasta figürünün çıplak vaziyette tasvir edilmeleri eserin tipik özellikleridir. Minyatürlerin birkaçı hariç diğer bütün tedavi sahneleri tabiatın içinde resmedilmiş, mekânsal betimlemeden uzak durulmuştur. ${ }^{47}$ Saray nakkaşları tarafından yapılan intişamlı sahnelerden, saray betimlemelerinden ve kullanılan malzeme (saray nakkaşhanelerinde bol miktarda altın kullanılırken bahsi geçen nüshada altın kullanımı nakkaşhane eserlerine göre azdır)ve teknik özellikleri bakımından farklı bir üsluptadır, bu da nüshanın da saray nakkaşhanesinde yapılmadığını destekler nitelikte bir özelliktir.

\section{Sonuç}

Cerrahiyetü'l Haniyye içerdiği tıbbi bilgiler neticesinde şimdiye kadar pek çok tıp bilimi kitabında yer almış eşsiz bir kaynaktır. Eser çeşitli tedavi yöntemlerini ayrıntılı bir şekilde ifade etmesi, bu yöntemlerin eski zamanlardan itibaren hangi isimlerle bilindiğine ve tedavilerinin alternatif tıp yöntemiyle nasıl gerçekleştirildiğine dair bilgilerin verilmesi açısından önemlidir. Bu bilgiler ışığında şimdiye kadar literatürde çoğu zaman içerdiği bilgilerin tercümesi ve tıbbi kitaplarda tedavilerin anlatılması amacıyla yer almıştır. Ancak dönemin önemli ilim ve sanat adamlarından biri olarak kabul ettiğimiz Sabuncuoğlu ve ortaya koyduğu eseri Cerrahiyyet'ül Haniyye, tıb ilminin yanında içerdiği minyatürleriyle de geleneksel sanatlarımızdan minyatür sanatı açısından önemli bir özelliğe sahiptir. Çalışmamızın yapılmasının ana nedeni de, söz konusu nüshanın minyatürleri hakkında şimdiye kadar böyle bir çalışmanın yapılmaması ve eserin sadece tıbbi bir eser olarak değerlendirilmiş olmasıdır.

Yapılan ayrıntılı analizler sayesinde resim ve metin arasındaki bağlantılar saptanmış ve metin kısmında bulunan bilgilerin birebir resmedildiği görülmüştür. Tüm resimlerde hekim, hasta ve alet resmini bir cümle ile açıklayan not bulunmaktadır. Bu açıklayıcı notlar düz satır şeklinde yerleştirilmişlerdir. Bu açıklayıcı notların hepsi lâl mürekkep ile yazılmış, siyah mürekkep ile harekelenmiştir.

Resimlerde beyaz, siyah, yavruağzı, sephia ile açık ve koyu olmak üzere

\footnotetext{
46 Kılıcoğlu, Cerrahiye-i ilhanniye, 25.

47 Güreşsever, “Kitab Al-Cerrahiyet Al-Hâniye (İstanbul Tıp Tarihi Enstitüsü Nüshası) Minyatürleri”, 773.
} 
farklı tonlarda sülyen, kırmızı, yeşil, mavi, sarı, kahverengi ve gri renkler kullanılmıştır. Beyaz, siyah, sephia ve yavruağzı renklerinin hep aynı tonlarda kullanıldığını söylemek mümkündür. Figürlerin bedenlerinin tahriri lâl mürekkep renginde iken; sarık ve kıyafetlerinin tahriri siyahtır.

Hekim, hekim yardımcısı ve hasta figürlerine giydirilen sarıkların tezyini yönleri değişiklik gösterse de sarıklar hep beyazdır. Tüm figürlerin gözleri ve tenleri; siyah ve yavruağzı olmak üzere hep aynı renkle boyanmıştır. Figürlerin alın, kaş altı ve yanak bölgelerinde görülen pembeliğin yoğunluğu figürden figüre değişmekle beraber bedenlerinin tahririnde kullanılan renkle aynı olduğu söylenilebilir.

Hekim ve hasta olmak üzere en az iki figür içeren tedavi ve ameliyat resimlerinde; ikinci hasta figürleri ile yardımcı hekim olarak nitelendirebileceğimiz başka figürlerde görülmektedir. Metin içerisinde kimliğine dair her hangi bir malumat bulunmasa da duruşundan yardımcı hekim olduğunu düşünebileceğimiz figürler içeren fasıllar da bulunmaktadır.

Hekim figürleri daima sağ tarafta oturur pozisyonda resmedilirken hasta figürlerinin oturuş şekilleri uygulanacak tedaviye göre değişiklik göstermektedir.

Minyatürlerdeki figürler anatomik olarak orantısızdır. Figürlerin el ve ayakları son derece küçük ve gelişigüzel çizilmiştir. Sözgelimi bazı fasıllardaki figürlerin elleri altı parmaklı çizilmiştir. Ayakta durur vaziyetteki tüm figürlerin üst bedenleri alt bedenlerinden daha büyük çizilmiştir. Hasta, hekim ve yardımcı hekim figürlerinin hepsinin gözleri iri ve birbirine yakındır.

Tüm fasıllarda birbirine benzer şekilde tasvir edilen hekim figürünün yüz hatları bazen daha küçük çizilmiştir. Diğer figürlerin birçoğunun çehreleri birbirine benzese de bazı figürlerin yüz hatları daha iri bir şekildedir. Hastaların yaşına dair metin içinde her hangi bir bilgi bulunmamaktadır fakat hastaların sakalsız yahut küçük çehreli çizilmelerinden dolayı çocuk yaşlarda olabileceği tahmininde bulunulmuştur.

Hekim figürü uzun aksakallı olarak tasvir edilmiştir. Resim içeren tüm fasıllarda hekimin beyaz çizgiler ile gri çizgilerden oluşan sakalları diğer figürlerinkinden daha uzundur. Yardımcı hekim figürlerinin tamamı sakalıdır. Hasta figürleri ise kimi zaman sakalı iken; kimi zaman da sakalsız resmedilmişlerdir. Sakal renkleri ve uzunlukları hasta figüründen hasta figürüne farklılık göstermektedir.

Hekim, hasta ve yardımcı hekim figürlerinden ayrı özel bir kıyafet giymemektedir. Yardımcı hekim figürlerinin tamamı deseni; uzun, düz kavisli çizgilerden oluşan uzun kıyafet giymektedir. Bunun dışında hasta ve hekim figürlerinin tamamı benzer desendeki kıyafetleri farklı fasıllarda tekrar tekrar giymektedir.

Resimler cetvel çizgisinin hemen üzerinde başlamaktadır ve resimlerde herhangi bir mekân olgusu bulunmamaktadır. Şematik olan resimlerin birçok 
faslında yerden bitme bitkisel dekor görülse de onun dış mekânda olduğuna işaret edecek bir başka unsur bulunmamaktadır. Ancak vazolara yerleştirilmiş çiçekler ve servilerin varlığı çizimleri bir mekan içerisinde gösterme arzusunu ortaya koyar.

Çalışma konumuzu teşkil eden Paris nüshası dahilinde diğer iki nüshanın da minyatür özellikleri bakımından mukayeselerle değerlendirdiğimizde, her üç nüshanın birbirinden farklı özellikler gösterdikleri tespit edilmiştir. Paris ve Millet Kütüphanesi nüshalarında bulunan minyatürlerin teknik ve üslup bakımından dönemin önemli sanat merkezi olan saray nakkaşhanesinde resmedilmediği, bu nüshanın saraya bağlı kalmadan hekimin kendisi tarafından Amasya'da resmedildiği anlaşılmaktadır. Ayrıca Paris nüshasında bulunan Sultan II. Bayezıd'ın tuğralı mührünün varlığı II. Bayezıd'ın babasının vefatından sonra onun kütüphanesindeki bütün kitapları kendi mührüyle mühürletmesi dolayısıyla eserin Fatih'in özel kitaplığında yer aldığının göstergesidir. İstanbul Tıp Tarihi nüshasının ise yine üslup ve yazı özellikleri bakımından daha geç bir dönemde yapıldığı sonucunu doğurmaktadır.

Cerrahiyyetü'l Haniyye gibi tarihi kaynakların güncelliğini yitirmeden her alanda tarihi bir ışık olarak korunması ve belgelendirilmesi akademik açıdan değerlidir. Çalışmamız kapsamında incelenen nüshanın mevcut eserin diğer bâblarında bulunan tedavi yöntemlerinin sadece bir kısmını kapsamaktadır. Bunun nedeni ilerleyen dönemde bütün nüshalarla ilgili olarak çalışmalar yapmayı planlamamızdır. Gerek tıp gerek sanat ve edebiyat tarihi bakımından değeri bulunan bu eserin çalışma konusuna dâhil edilmesiyle tekrar değerlendirilerek eserin günümüz literatüründe vesikalandırılmasını önem arz etmektedir.

\section{Kaynaklar}

» Acar, Volkan. “Yazılışının 550. Yılında Cerrahiyetü'ı Haniyye Hakkında SCl-E Kapsamındaki Dergilerde Yayınlanan Türkiye Kaynaklı Makaleler”. Mersin Üniversitesi Tıp Fakültesi Lokman Hekim Tıp Tarihi ve Folklorik Tıp Dergisi 5/2 (2015), 37-44.

" Bademci, Gülşah. "First Illustrations of Female "Neurosurgeons" In The Fifteenth Century By Serefeddin Sabuncuoglu”. Neurocirugía 17/2 (Nisan 2006), 162-165.

" Bayat, Ali Haydar. "Cerrâhiyye-i İlhâniyye". Türkiye Diyanet Vakfı İslâm Ansiklopedisi. 7/420, Ankara: TDV Yayınları,1993.

" Baysal, Ali Fuat. "Mushaf Tezyinatının Tarih İçindeki Gelişimi”. Marife Dini Araştırmalar Dergisi. 10/3 (2010), 365-386.

" Canda, M. Şerafettin. “Türkiye'de Nöropatoloji Gelişimi Dünden Bugüne”. Türkiye Ekopatoloji Dergisi 11/3 (2005), 93-158.

» Doğan, Şaban, Terceme-i Akrabâdin Sabuncuoğlu Şerefeddin (Giriş-Incleme-Metinler) Birinci Cilt. Sakarya: Sakarya Üniversitesi, Sosyal Bilimler Enstitüsü, Doktora Tezi, 2009.

" Eroğlu, Haldun. "XV. Yüzyıl Hekimlerinden Şerefeddin Sabuncuoğlu ve Amasya Dârüşşifâsı”. Ankara Üniversitesi Osmanlı Tarihi Araştırma ve Uygulama Merkezi Dergisi 11(2000), 147-156.

" Güreşsever, Gönül. “Kitab Al-Cerrahiyet Al-Hâniye (İstanbul Tıp Tarihi Enstitüsü Nüshası) Minyatürleri”. I. Milletlerarası Türkoloji Kongresi (15-20 Ekim 1973): Tebliğler. 3/771794. İstanbul: İstanbul Üniversitesi Edebiyat Fakültesi Türkiyat Enstitüsü Yayınları, 1979.

» Kılıcıoğlu, Vecihe. Cerrahiye-i Ilahniyye. Ankara: Türk Tarih Kurumu Basımevi, 1. Basım, 1956.

" Murad, Sibel. “Terceme-i Akrabâdîn'de Terkipler ve Adlandırılmaları”. Osmanlı Bilimi Araştırmaları Dergisi 12/2(2011), 81-94. 
» Sabuncuoğlu, Şerefeddin. Cerrahiyyet'ül Haniyye, İstanbul: Millet Kütüphanesi, Ali Emiri (Tıp) Kitaplığı, 79.

"Sabuncuoğlu, Şerefeddin. Cerrahiyyet'ül Haniyye. Fransa: Paris Bibliothéque Nationale. Suppl., Turcs, 693.

» Şehsuvaroğlu, Bedi N. “Anadolu'da Türkçeleşme Cereyanları ve Türkçe İlk Tıp Yazmalarındaki Terimler". VIII. Türk Dil Kurultayında Okunan Bilimsel Bildiriler. 29. Ankara: Türk Tarih Kurumu Basımevi, 1960.

» Şenel, Ünal. Amasya'lı Hekim Sabuncuoğlu Şerefeddin'in Eseri Mücerreb-nâme. İzmir: Ege Üniversitesi, Sağlık Bilimleri Enstitüsü, Yüksek Lisans Tezi, 1988.

» Uzel, İlter. Cerrahiyyetü'l-Haniyye I-II. Ankara: Türk Tarih Kurumu Basımevi, 1. Basım, 1992.

» Ünver, A.Süheyl. Cerrahiyei İlhaniye. İstanbul: Kenan Basımevi ve Klişe Fabrikası, 1. Basım, 1939.

" Yetkin, Suut Kemal. “İslam Minyatürünün Estetiği”. Ankara Üniversitesi Ilahiyat Fakültesi Dergisi 1(1953), 33-39.

» Yavuz, Serdar. Cerrah-nâme, İstanbul: Kesit Yayınları, 1. Basım, 2013.

» Yıldırım, Nuran. “On Beşinci Yüzyıla Ait Türkçe Cerrahnâmeler”. Lokman Hekim Journal 1/1 (2011), 19-28.

" Yıldııım, Nuran. "Sabuncuoğlu Şerefeddin”, Türkiye Diyanet Vakfı İslâm Ansiklopedisi,. Erişim 09 Kasım 2019. https://islamansiklopedisi.org.tr/sabuncuoglu-serefeddin 